Studies in African Linguistics

Volume 25, Number 2, Fall 1996

\title{
LINES ON THE CLASSIFICATION OF ETHIOPIAN-SEMITIC
}

\author{
Jack Fellman \\ Bar-Ilan University, Israel
}

Ethiopian-Semitic constitutes a compact, readily defined and homogeneous linguistic family, consisting of Ge'ez, Tigre, Tigrinya, Amharic, Argobba, Harari, Gafat, and the Gurage cluster. The most recent attempt to set up a classification of Ethiopian-Semitic was Hetzron [1972\}, but this work was rather thoroughly criticized by Goldenberg [1977], and the field has yet to recover from it. The present note seeks to open the classification question anew by providing a basic, minimalist classification scheme, which can serve as a starting-off point for any future work on the subject. We begin with some of the results of Marcel Cohen [1931], "the father of Ethiopian studies" in the twentieth century. Cohen treats Tigre and Tigrinya as Northern Ethiopic, and Amharic, Harari, and the Gurage cluster as Southern Ethiopic. All are ultimately descendants of a ProtoEthiopic koiné most closely resembling Ge'ez. Gurage, according to Cohen, is not a language or a linguistic unit in itself, but rather an ensemble of at least two separate and mutually unintelligible dialect clusters, Eastern Gurage and Western Gurage. Eastern Gurage consists of Wolane, Selti-Ulbarag, (and in the present state of our knowledge also Zway), and is most closely connected with Harari. Western Gurage consists of several subgroups of dialects, in particular (a) Chaha, Ezha, Ennemor (Inor), Gumar, Gyeto (and in the present state of our knowledge Endegeñ) and (b) Muher, Gogot, Mäsqan. Aymallel (Soddo, Kəstanəňña), another Gurage tongue, is left unclassified by Cohen, as being perhaps intermediate between the two groups. Tentatively, he terms it North-Eastern Gurage. (Gafat and Argobba are not classified by Cohen.)

Cohen's classification may be modified and/or expanded on the basis of the following points.

1. Polotsky [1949:37, text and footnote 5] noted that Soddo is clearly a Western Gurage tongue.

2. Leslau [1960], on the basis of work in the 1940's and 1950's, showed that (a) Argobba is most closely connected with Amharic, and indeed may be considered a conservative dialect of the language and (b) Gafat is most closely connected with Soddo. Indeed, Polotsky [1949:37, text and footnote 5] had 
already noted that Gafat has "striking affinities" to Western Gurage in particular, and especially to Soddo (and Muher).

3. Goldenberg [1968:62-63] noted that Gogot "is a somewhat modified form" of Soddo "adequately understood" by Soddo speakers. Hetzron [1972:2] similarly noted that Soddo-speakers consider Gogot "a Soddo dialect" and that the two groups understand each other "fairly well".

Adding these comments to Cohen's 1931 classification, we obtain the following diagram, which, we submit, can be taken as the basis for any future classification of Ethiopian Semitic.

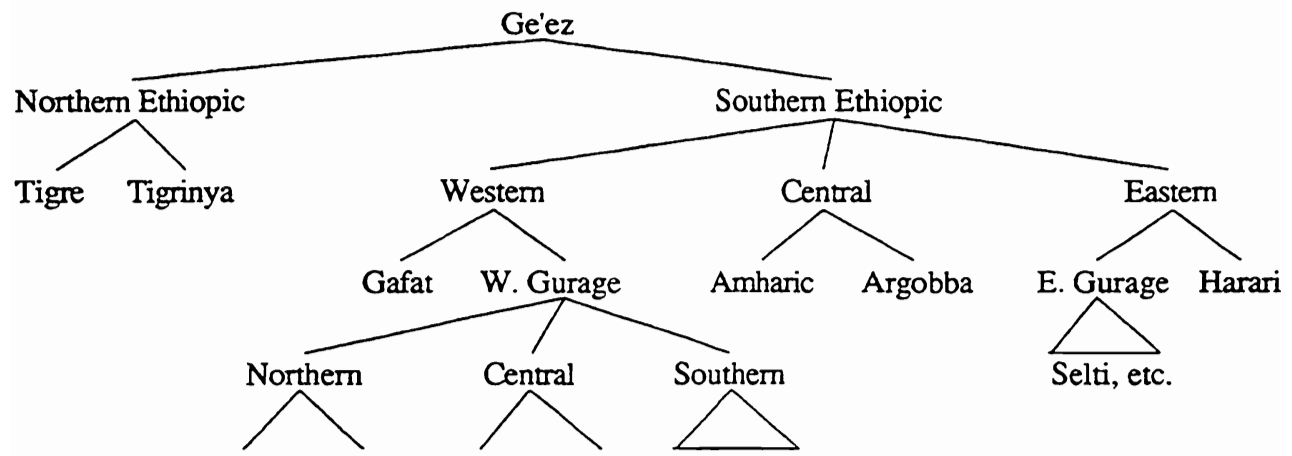

Soddo Gogot Muher Mäsqan Chaha, etc.

\section{REFERENCES}

Cohen, Marce1. 1931. Études d'éthiopien méridional. Paris: P. Guenther.

Goldenberg, Gideon. 1968. “Kəstanəňňa.” Orientalia Suecana 17:61-102.

Goldenberg, Gideon. 1977. "The Semitic Languages of Ethiopia and their Classification." Bulletin: School of Oriental and African Studies 40:461-507.

Hetzron, Robert. 1972. Ethiopian Semitic: Sketches in Classification. (Journal of Semitic Studies, Monograph 2). Manchester: Manchester University Press.

Leslau, Wolf. 1960. "Sketches in Ethiopic Classification." Atti del Convegno Internazionale di Studi Etiopie, Accademia Nazionale dei Lincei, Rendiconti, 48:89-107.

Polotsky, Hans Jakob. 1949. Review of Leslau: Gafat Documents. Journal of the American Oriental Society 69:36-41. 